\title{
Properties of Amorphous Silica Synthesized from Copper-Smelting Slags
}

\author{
M.Sh. Kurbanov ${ }^{1}$, S.A. Tulaganov ${ }^{1}$, M. Ernazarov ${ }^{1}$, L.S. Andriyko, ${ }^{2,3}$, A.I. Marinin ${ }^{3}$, A.Yu. Shevchenko ${ }^{3}$ \\ ${ }^{1}$ Institute of Ion-Plasma and Laser Technologies named after U.A. Arifov, 33, Durmon Yuli St., \\ 100125 Tashkent, Uzbekistan \\ ${ }^{2}$ Chuiko Institute of Surface Chemistry, 17, General Naumov St., 03164 Kyiv, Ukraine \\ ${ }^{3}$ National University of Food Technology, 68, Volodymyrska St., 01033 Kyiv, Ukraine
}

(Received 11 November 2021; revised manuscript received 04 December 2021; published online 20 December 2021)

\begin{abstract}
Highly dispersed powders of amorphous silica (silicon dioxide) with a purity of $99.98 \%$ using ammonium fluoride were synthesized from the man-made waste of copper-smelting production. The amorphous state of the obtained silica samples was confirmed by XRD analysis. It was found that the particle size distribution of $\mathrm{SiO}_{2}$ in an aqueous medium is mainly represented by aggregates $(100-220 \mathrm{~nm})$ and agglomerates of aggregates $(1300$ and $5500 \mathrm{~nm})$. It is shown that an increase in the time of ultrasonic treatment does not significantly affect the bi- or trimodal character of the particle size distribution. The effective diameter $D_{\text {ef }}$ of agglomerates of silica particles decreases by 3 times during the first 10 min of ultrasonic treatment. With a subsequent increase in the processing time, $D_{e f}$ does not change significantly, but fluctuates around some specific value. IR spectra of silica samples have characteristic bands related to bending vibrations of $\mathrm{Si}-\mathrm{O}-\mathrm{Si}$ at $468 \mathrm{~cm}^{-1}$ (intense) and $\mathrm{O}-\mathrm{Si}-\mathrm{O}$ at $800 \mathrm{~cm}^{-1}$ (average intensity), as well as bands related to stretching vibrations of $\mathrm{Si}-\mathrm{O}-\mathrm{Si}$ in the range $1000-1200 \mathrm{~cm}^{-1}$, which are responsible for the reactivity. It was found that the process of thermal desorption from the surface of the $\mathrm{SiO}_{2}$ sample proceeds in several stages, with the most intense release of the following main volatile products: $\mathrm{O}(\mathrm{m} / \mathrm{z} 16), \mathrm{OH}(\mathrm{m} / z$ 17), $\mathrm{H}_{2} \mathrm{O}(\mathrm{m} / z$ 18), and $\mathrm{CO}(\mathrm{m} / z 28)$. The textural characteristics of the synthesized powders were determined by the method of low-temperature nitrogen adsorption. It is shown that the shape of the adsorption isotherm and the hysteresis loop corresponds to the texture porosity of aggregates of non-porous nanomaterials. The adsorption isotherm is well linearized, which made it possible to calculate the specific surface area according to BET $\left(64 \mathrm{~m}^{2} / \mathrm{g}\right)$ and Langmuir $\left(93 \mathrm{~m}^{2} / \mathrm{g}\right)$, the total pore volume, micropores, and the total area of micropores.
\end{abstract}

Keywords: Synthesis, Ammonium fluoride, Industrial waste, Highly dispersed powders, Amorphous silicon dioxide, Particle size distribution.

DOI: $10.21272 /$ jnep.13(6).06024

PACS number: $61.46 .+\mathrm{w}$

\section{INTRODUCTION}

Amorphous silica, silicon dioxide $\left(\mathrm{SiO}_{2}\right)$, can be obtained naturally or synthetically, and is known to have a wide range of applications. Despite numerous studies over the past few decades, the investigation of the structural properties of amorphous silica and composite materials based on it continues to arouse great interest among both researchers and consumers of this product. This is due, firstly, to its widespread use in various industries (construction, rubber industry, production of adhesives, gels and sealants, as well as the creation of heat-resistant materials, polymers, hydrophobic and antifriction coatings, etc.) [1-5]. Composite materials based on highly dispersed amorphous silica are also widely used in optoelectronics and optotelecommunication technologies [6,7]. Secondly, the study of the amorphous silica structure makes it possible to reveal its new properties, which depend heavily on the method and conditions of synthesis, as well as on the characteristics of the raw materials $[7,8]$.

At present, to obtain highly dispersed powders of silicon dioxide, both chemical (sol-gel, pyrolysis, plasma-chemical) and physical (dispersion, electron-beam, laser ablation and plasma-arc) methods are used [9-14]. The traditional methods used for the synthesis of highly dispersed $\mathrm{SiO}_{2}$ powders have their own advantages, but also disadvantages, including the multistage process, high cost of equipment, special and expensive raw materials used, etc.
In this work, the study of the properties of highly dispersed $\mathrm{SiO}_{2}$ powders synthesized from industrial waste (copper smelting slags) with a specific chemical composition and structure using ammonium fluoride was carried out [15-17].

Thus, the question of the connection between the structural and other characteristics of silicon dioxide is of purely practical importance when using materials based on it as a filler, since the definition of the "structure - property" dependence will allow direct control over the synthesis of new materials.

\section{EXPERIMENT}

\subsection{Materials}

Slags from the copper-smelting production of the Almalyk Mining and Metallurgical Combine (AMMC) are the product of the smelting process of copper concentrates containing copper from 10 to $30 \%$, which are obtained by beneficiation of sulfide copper-molybdenum ores. In this work, dump slags of copper production were used. According to the chemical composition, their main macrocomponents are silicon dioxide $\mathrm{SiO}_{2}$ and $\mathrm{Fe}$ with a content (wt. \%) of 29.8-40.0 and 30.7-41.4, respectively. The content of other components, $\mathrm{Al}_{2} \mathrm{O}_{3}$ (up to $6.0 \%$ ), $\mathrm{CaO}$ (up to $2.5 \%$ ), $\mathrm{Cu}$ (up to $0.9 \%$ ), $\mathrm{MgO}$ (1.3\%), Zn (1.2\%) etc., is insignificant.

Thus, the use of dump slags from AMMC is aimed at developing resource-saving technologies and solving 
environmental problems associated with the utilization of man-made waste from mining and metallurgical industries.

\subsection{Synthesis}

For the synthesis of highly dispersed particles of amorphous silica dioxide, ammonium fluoride $\left(\mathrm{NH}_{4} \mathrm{~F}\right.$, Guangzhou Yijia Supply Chain Co Ldt, China) $\geq 98 \%$ purity) was used. Fluorination was carried out in a specially designed reactor made of nickel alloy according to the following reaction:

$$
\mathrm{SiO}_{2}+6 \mathrm{NH}_{4} \mathrm{~F}=\left(\mathrm{NH}_{4}\right)_{2} \mathrm{SiF}_{6}+4 \mathrm{NH}_{3}+2 \mathrm{H}_{2} \mathrm{O} .
$$

After filtration, by separation from the $\left(\mathrm{NH}_{4}\right)_{2} \mathrm{SiF}_{6}$ solution under the action of ammonia water $\left(\mathrm{NH}_{4} \mathrm{OH}\right)$, according to the reaction

$$
\left(\mathrm{NH}_{4}\right)_{2} \mathrm{SiF}_{6}+4 \mathrm{NH}_{4} \mathrm{OH}=\mathrm{SiO}_{2}+6 \mathrm{NH}_{4} \mathrm{~F}+2 \mathrm{H}_{2} \mathrm{O}
$$

a highly dispersed powder of amorphous $\mathrm{SiO}_{2}$ was obtained.

\subsection{Characterization}

X-ray diffraction (XRD) patterns were obtained on a DRON-4-07 X-ray diffractometer (NPO Burevestnik, St. Petersburg, Russia) in filtered $\mathrm{CoKa}$ radiation with the Bragg-Brentano survey geometry. Diffraction patterns were recorded in the $2 \theta$ angle range from 10 to $70^{\circ}$ at room temperature with a step of $0.05^{\circ}$ and exposure at a point of $1 \mathrm{~s}$. A glass cell was used as a substrate.

Particle size distribution (PSD) was studied using a Zetasizer Nano ZS (Malvern Instruments) apparatus using a universal dip cell (ZEN1002) with a wavelength of $\lambda=633 \mathrm{~nm}$ and a scattering angle of 13 and $176^{\circ}$. Accuracy and reproducibility of particle size are $\pm 1-2 \%$. Suspensions of synthesized silicon dioxide samples with a concentration of $C_{\mathrm{SiO} 2}=1 \mathrm{wt}$. \% were prepared in deionized water using ultrasonic dispersion (Sonopuls HD 2040 homogenizer, Bandelin, $20 \mathrm{kHz}, 80 \mathrm{~W}$ ). To carry out measurements and to process the results obtained, a computer program from Malvern Instruments was used, which assumes that the particles are spherical.

The transmittance infrared (IR) spectra were recorded in the range of $4000-300 \mathrm{~cm}^{-1}$ using a Specord M80 (Carl Zeiss, Germany). The samples were mixed with $\mathrm{KBr}$ (Sigma-Aldrich, for spectroscopy) in a ratio of $1: 100$, stirred and pressed into thin pellets $8 \pm 28 \mathrm{~mm}$ in size and $20 \pm 0.5 \mathrm{mg}$ in mass.

Thermal desorption mass spectra were studied using one-pass (OP) temperature programmed desorption (TPD) time-of-flight (ToF) method with massspectrometry (MS) control using a MSC-3 ("Electron", Sumy, Ukraine) ToF mass-spectrometer [18]. The pressure in the chamber was $4 \times 10^{-6} \mathrm{~Pa}$, the sample mass was $7 \mathrm{mg}$ (with a short distance $(\sim 0.5 \mathrm{~cm})$ between the sample and the MS detector), and the heating rate $(\beta)$ was $1.2 \mathrm{~K} / \mathrm{s}$. The sample was heated to a maximum temperature of $600{ }^{\circ} \mathrm{C}$ in 75 min linearly in time at a rate of $0.15^{\circ} \mathrm{C} / \mathrm{s}$. At the same time, with the heating of the sample, the mass spectra were recorded on a computer, from which the data on the time variation of the amplitude of the required components were then ex- tracted and the dependences $I_{m}(t)$ were plotted.

To analyze the textural characteristics of the obtained amorphous silicon dioxide powders, lowtemperature $(77.4 \mathrm{~K})$ nitrogen adsorption-desorption isotherms were recorded on a Kelvin-1042 adsorption analyzer (Costech Microanalytical). The samples were degassed at $110{ }^{\circ} \mathrm{C}$ for $2 \mathrm{~h}$ in a vacuum chamber. The values of the specific surface area $\left(\mathrm{S}_{B E T}\right)$ were calculated according to the standard BET method [19]. The total pore volume $V_{p}$ was evaluated from the nitrogen adsorption at $p / p_{0} \approx 0.98-0.99$, where $p$ and $p_{0}$ denote the equilibrium and saturation pressures of nitrogen at $77.4 \mathrm{~K}$, respectively [20].

\section{RESULTS AND DISCUSSION}

\subsection{Synthesis of Amorphous $\mathrm{SiO}_{2}$ Particles}

The synthesis of amorphous $\mathrm{SiO}_{2}$ particles was carried out according to reaction (2). For this, ammonium hexafluorosilicate $\left(\mathrm{NH}_{4}\right)_{2} \mathrm{SiF}_{6}$ was treated with ammonia water with a concentration of $10-25 \%$ at a $\mathrm{pH}$ of 8-9 and a temperature of $25^{\circ} \mathrm{C}$. After filtration from the $\left(\mathrm{NH}_{4}\right)_{2} \mathrm{SiF}_{6}$ solution, a highly dispersed powder of amorphous $\mathrm{SiO}_{2}$ was obtained, having a purity of $99.98 \%$, according to mass spectrometry data.

The efficiency of the process of ammonia hydrolysis $\left(\mathrm{NH}_{4}\right)_{2} \mathrm{SiF}_{6}$ depends on the values of its concentration in the solution [16]. $\left(\mathrm{NH}_{4}\right)_{2} \mathrm{SiF}_{6}$ solutions were prepared with a concentration of $3,10,20$, and $30 \mathrm{wt} . \%$, from which $\mathrm{SiO}_{2}$ particles were synthesized at the above temperature. The indicators of silicon dioxide extraction were as follows: at a concentration of $3 \mathrm{wt} . \%$ of $\left(\mathrm{NH}_{4}\right)_{2} \mathrm{SiF}_{6}-98 \%$; at 10 wt. \% - $75 \%$; at 20 wt. \% $87.5 \%$, and at 30 wt. $\%-75 \%$. Thus, a 10 -fold increase in the concentration of ammonium hexafluorosilicate leads to a decrease in product extraction by $25 \%$.

\subsection{X-ray Powder Diffraction Analysis}

The XRD pattern of synthesized amorphous silicon dioxide powder is characterized by the presence of a wide halo in the range of $2-20^{\circ}$, which corresponds to the presence of X-ray amorphous material in the sample (Fig. 1).

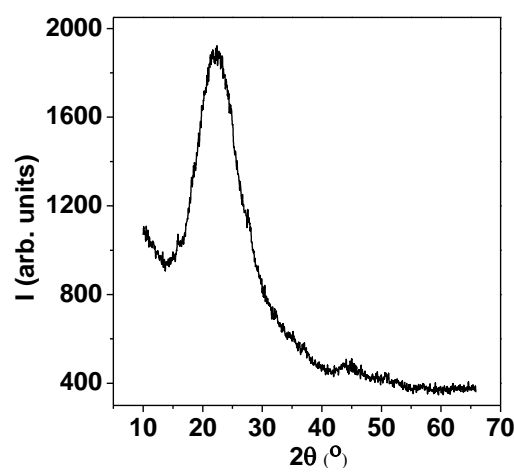

Fig. 1 - XRD pattern of amorphous silicon dioxide powder obtained from dump slags of copper smelting production

\subsection{Particle Size Distribution in Aqueous Medium}

It was revealed by laser correlation spectroscopy that the PSD of amorphous $\mathrm{SiO}_{2}$ in an aqueous medium 
is polymodal and is represented mainly by aggregates of $100-220 \mathrm{~nm}$ and agglomerates with a maximum at 1300 and $5500 \mathrm{~nm}$ (Fig. 2). An increase in the time of ultrasonic treatment of aqueous suspensions of silicon dioxide samples from 1 to 25 min does not significantly affect the PSD nature. This indicates the formation of sufficiently strong micron-sized agglomerates, which is apparently due to the type of synthesis and subsequent material processing. At the same time, it can be seen from Fig. 2 that with an increase in the processing time, the maximum values of PSD decrease almost by more than 2 times, for example, in the Intensity curve from 1300 (at $1 \mathrm{~min}$ ) to $600 \mathrm{~nm}$ (at $25 \mathrm{~min}$ ) and in the Number curve - from 220 to $100 \mathrm{~nm}$, which can be explained by the partial destruction of agglomerates.
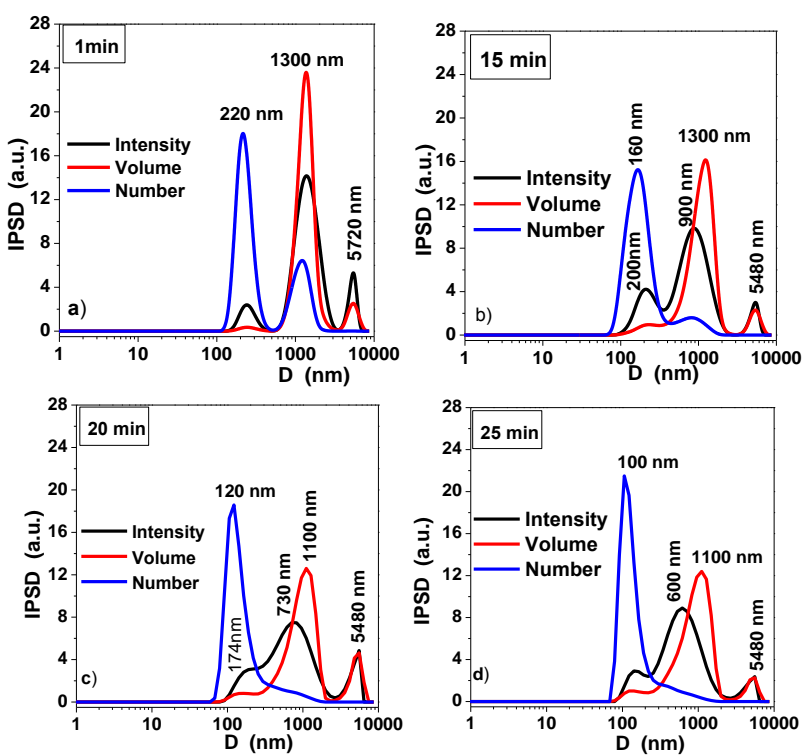

Fig. 2 - PSD related to the intensity of light scattering $(I)$, the volume $(V)$ and the number of synthesized silica particles $(N)$, depending on the time of ultrasonic treatment in am aqueous medium $\left(C_{\mathrm{SiO} 2}=1\right.$ wt. $\left.\%\right)$

The effective diameter $\left(D_{e f}\right)$ is the average value of the diameter of the particles in the dispersion, which makes it easier to estimate the change in particle size during processing. $D_{e f}$ values were determined by the intensity of the scattered light

$$
D_{e f}=\sum_{i} N_{i} d_{i}^{6} / \sum_{i} N_{i} d_{i}^{5}
$$

where $d_{i}$ and $N_{i}$ are the diameter and number of the $i$-th particle, respectively [21, 22].

The effective particle diameter of the studied silica samples depends on the time of ultrasonic treatment (Fig. 3). During the first $10 \mathrm{~min}$, there is a significant decrease in $D_{\text {ef }}$ from 1600 to $659 \mathrm{~nm}$ (2.4 times). With a further increase in the ultrasonic treatment time, the $D_{\text {ef }}$ value is in the range of 633-467 nm. This effect can be associated with balancing between the processes of destruction of aggregates and their formation: disaggregation $\leftrightarrow$ aggregation. Therefore, in this case, according to the $D_{\text {ef }}$ value, it is correct to estimate not the particles size in the suspension, but the equilibration time between the processes of destruction and formation of aggregates (when $D_{\text {ef }}$ stops decreasing).

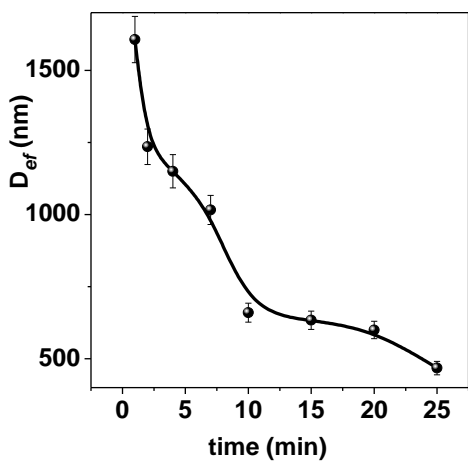

Fig. 3 - The effective diameter of $\mathrm{SiO}_{2}$ particles (determined from the scattered light intensity) as a function of the time of ultrasonic treatment in an aqueous medium $\left(C_{\mathrm{SiO} 2}=1 \mathrm{wt} . \%\right)$

\subsection{IR Spectroscopy}

The IR spectra of silica showed the presence of characteristic bands of bending vibrations $\mathrm{Si}-\mathrm{O}-\mathrm{Si}$ at $468 \mathrm{~cm}^{-1}$ (intense) and O-Si-O at $800 \mathrm{~cm}^{-1}$ (medium intensity) and bands of stretching vibrations $\mathrm{Si}-\mathrm{O}-\mathrm{Si}$ in the range of $1000-1200 \mathrm{~cm}^{-1}$ (Fig. 4a). This distinct band characterizes the reactivity of silica. The bands at $1636,3200-3500 \mathrm{~cm}^{-1}$, related to adsorbed water, which is associated with silanol groups by hydrogen bonds, indicate its significant content in the sample (Fig. 4b).
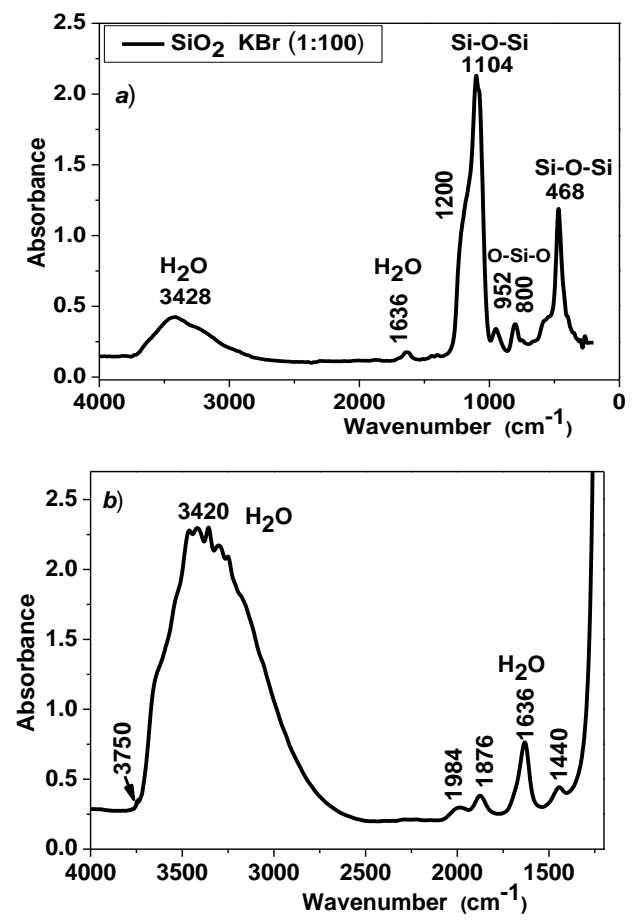

Fig. 4 - The IR spectra of amorphous silicon dioxide powder: a) mixed with $\mathrm{KBr}$ in a ratio of $1: 100, \mathrm{~b}$ ) initial, taken for transmission

\subsection{TPD Mass Spectra}

The mass spectra of the products of thermoprogrammed desorption from the surface of the synthesized $\mathrm{SiO}_{2}$ sample at two temperatures $\left(T=27^{\circ} \mathrm{C}\right.$ and $T=600^{\circ} \mathrm{C}$ ) are shown in Fig. 5a. Interpretation of the most intense signals in the mass spectra indicates that the most probable volatile products are $\mathrm{H}_{2}(\mathrm{~m} / z 2), \mathrm{O}$ 
$(\mathrm{m} / z 16), \mathrm{OH}(\mathrm{m} / z 17), \mathrm{H}_{2} \mathrm{O}(\mathrm{m} / z 18), \mathrm{CO}(\mathrm{m} / z 28), \mathrm{CO}_{2}$ $(m / z 44), \mathrm{NO}_{2}(m / z 44)$. Analysis of the TPD mass spectra shows that at low temperatures of the sample, the lines of $\mathrm{H}_{2}(\mathrm{~m} / z 2)$ and $\mathrm{CO}_{2}(\mathrm{~m} / z 44)$ are the main ones. At high temperatures, the lines of $\mathrm{m} / z=17,18$ indicate that hydroxyl radicals $\mathrm{OH}$ and water molecules $\mathrm{H}_{2} \mathrm{O}$ are the main products of TPD.
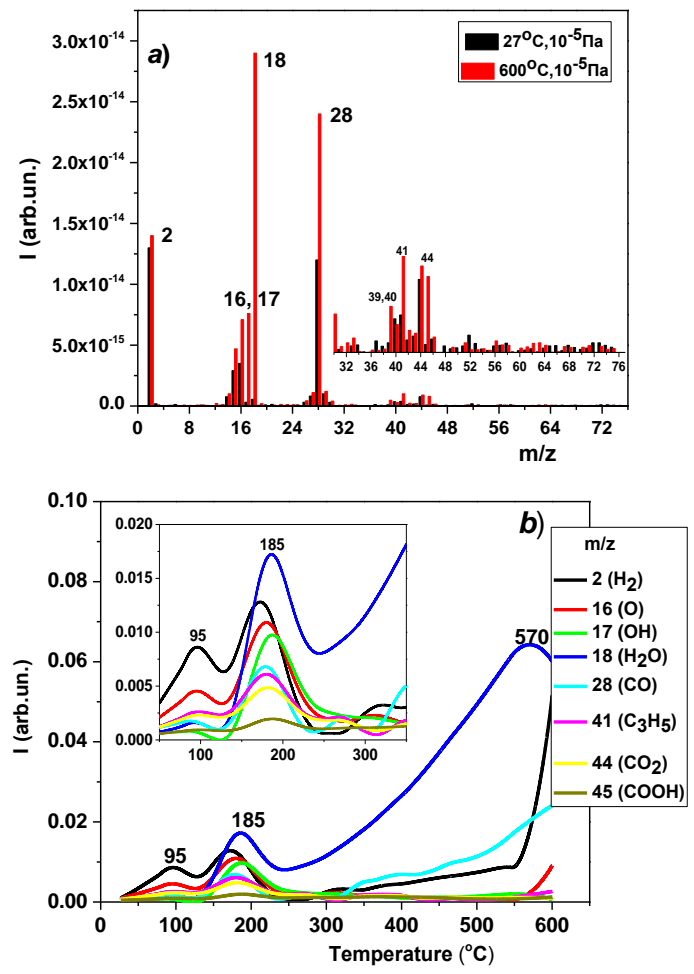

Fig. 5 - TPD mass spectra obtained during thermolysis of the $\mathrm{SiO}_{2}$ sample at $T=27$ and $600{ }^{\circ} \mathrm{C}$ (a) and thermograms of the main desorption products: $\mathrm{H}_{2}(\mathrm{~m} / z 2), \mathrm{O}(\mathrm{m} / z 16), \mathrm{OH}(\mathrm{m} / z 17)$, $\mathrm{H}_{2} \mathrm{O}(\mathrm{m} / z 18), \mathrm{CO}(\mathrm{m} / z 28), \mathrm{CO}_{2}(\mathrm{~m} / z 44), \mathrm{NO}_{2}(\mathrm{~m} / z 44)$ (b)

According to the analysis of the thermograms of the main products (Fig. 5b) desorbed from the surface of the $\mathrm{SiO}_{2}$ sample, the desorption process occurs in two or three stages. Molecular hydrogen is desorbed in three stages at temperatures of 95,170 and $600{ }^{\circ} \mathrm{C}$, apparently due to the type of bonds with the surface (low-temperature hydrogen may be responsible for van der Waals forces and chemisorption, high-temperature hydrogen - for diffusion from the volume). For curves of oxygen, hydroxyl radical and water, only two desorption stages are observed. The desorption curve of $\mathrm{H}_{2} \mathrm{O}$ as the main component confirms the presence of a large amount of adsorbed water in the sample (Fig. 4). The process of $\mathrm{H}_{2} \mathrm{O}$ desorption occurs in three stages at different temperature maxima: at $T_{\max }=95$ and $185^{\circ} \mathrm{C}$, adsorbed water is released, the release area $250-570{ }^{\circ} \mathrm{C}$ is probably associated with the process of dehydroxylation of the surface of the $\mathrm{SiO}_{2}$ sample, since there are several types of $\mathrm{OH}$ groups on the silica surface (single, vicinal and geminal $\mathrm{OH}$ groups, hydrogen-bonded and free) [22]. The desorption stage at $T_{\max }=185^{\circ} \mathrm{C}$ (Fig. 5b) presumably is related to the products of $\mathrm{CO}$ and $\mathrm{CO}_{2}$. The wide maximum for $\mathrm{m} / z 44$ can be responsible for both $\mathrm{COOH}$ and $\mathrm{NO}_{2}$. This may be due to the fragmentation of hydrocarbons under the action of an electron beam used as an ionization source.

\subsection{Textural Characterization}

The nitrogen adsorption isotherm for the obtained silicon dioxide sample is $S$-shaped. This isotherm shape implies the presence of polymolecular adsorption. The curved initial section indicates a strong interaction of the adsorbate with the silica surface. At high pressures, the isotherm has a bend with a hysteresis loop (type IV) corresponding to the textural porosity of aggregates of nonporous nanoparticles (Fig. 6a). The shape of the hysteresis loop indicates the dominant contribution of mainly cylindrical mesopores (filled with adsorbed nitrogen during measurements) [19, 21].

A study of the specific surface area and sorption capacity of the samples by the method of low-temperature nitrogen adsorption showed that $\mathrm{SiO}_{2}$ samples have a maximum specific surface area of about $64 \mathrm{~m}^{2} / \mathrm{g}$ according to BET and $93 \mathrm{~m}^{2} / \mathrm{g}$ according to Langmuir. The total pore volume is $218 \mathrm{~mm}^{3} / \mathrm{g}$, including $3.7 \mathrm{~mm}^{3} / \mathrm{g}$ of micropores. The total area of micropores is $10.5 \mathrm{~m}^{2} / \mathrm{g}$, the non-microporous surface is $53.4 \mathrm{~m}^{2} / \mathrm{g}$. The pore size distribution curves calculated from nitrogen adsorption-desorption isotherms show three characteristic maxima related to mesopores $(R=2-50 \mathrm{~nm}$ ) (Fig. 6b). Narrow voids between particles closely located in the same aggregates can also contribute to the porosity of the tested sample.
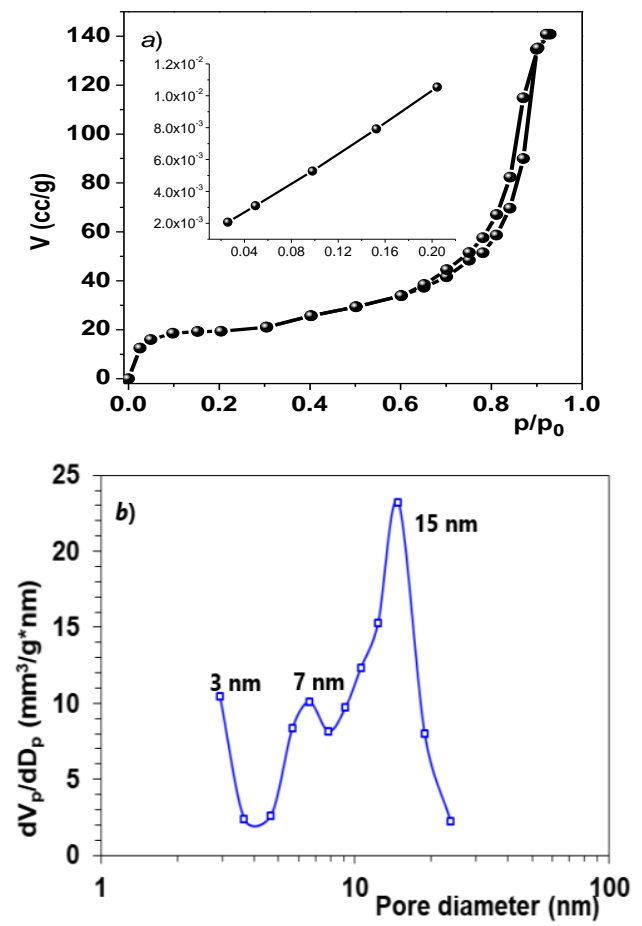

Fig. 6 - Nitrogen adsorption-desorption isotherm (a), incremental pore size distribution for synthesized silica dioxide (b) 


\section{CONCLUSIONS}

The efficiency of hydrolysis of $\left(\mathrm{NH}_{4}\right)_{2} \mathrm{SiF}_{6}$ depends on time and concentration of ammonia. In this case, the maximum extraction of $\mathrm{SiO}_{2}$, equal to $98 \%$, occurs at a concentration of ammonium hexafluorosilicate of 3 wt. \%. Further increase in the concentration of $\left(\mathrm{NH}_{4}\right)_{2} \mathrm{SiF}_{6}$ up to $30 \mathrm{wt} . \%$ leads to a decrease in the amount of recovered silicon dioxide to 75 wt. \%. Thus, an increase in the concentration of $\left(\mathrm{NH}_{4}\right)_{2} \mathrm{SiF}_{6}$ in the solution during hydrolysis by a factor of 10 leads to a decrease in the yield of silicon dioxide by $25 \%$.

Using the method of X-ray phase analysis, the amorphous state of the obtained $\mathrm{SiO}_{2}$ samples was confirmed. It was found that the PSD of amorphous $\mathrm{SiO}_{2}$ in an aqueous medium at a concentration of $1 \mathrm{wt} . \%$ is polymodal and is mainly represented by aggregates $(100-220 \mathrm{~nm})$ and agglomerates of aggregates (1300$5500 \mathrm{~nm})$. An increase in the time of ultrasonic treatment does not significantly change the nature of the PSD. However, with an increase in the time of ultrasonic treatment to $25 \mathrm{~min}$, a shift of the PSD curves related to intensity towards lower values is observed, which may be associated with partial destruction of agglomerates. The effective diameter $D_{\text {ef }}$ of agglomerates of silicon dioxide particles decreases significantly during the first $10 \mathrm{~min}$ of ultrasonic treatment (by

\section{REFERENCES}

1. M. Davraz, L. Gunduz, Cement Concrete Res. 35 No 7, 1251 (2005).

2. N.C. Camacho, J.R. Vega Baudrit, Y.C. Urena, Organic \& Medicinal Chem. I J. 5 No 1, 555654 (2018).

3. P.V. Grishin, Vestnik Kazanskogo Tehnologicheskogo Universiteta 17 No 18, 239 (2014).

4. The Surface Properties of Silica (Ed. by A.P. Legrand) (John Wiley \& Sons Ltd: 1998).

5. Himija Poverhnosti Kremnezema: $v 2$ ch., (Ed. by A.A. Chuiko) (Kiev: Nauk. Dumka: 2001).

6. S. Das, J. Manam, S.K. Sharma, J Mater Sci: Mater Electron. 27 No 12, 13217 (2016)

7. T. Uchino, J. Ceram. Soc. Jpn. 113 No 1, 17 (2005)

8. L. Khouchaf, K. Boulahya, P. Pratim Das, S. Nicolopoulos, V.K. Kis, J.L. Labar, Materials 13, 4393 (2020).

9. E. Tranquillo, F. Barrino, G.D. Poggetto, I. Blanco, Materials 12 No 1, 155 (2019).

10. H.N. Azlinaa, J.N. Hasnidawania, H. Noritaa, S.N. Surip, Acta Physica Polonica A 129 No 4, 842 (2016).

11. N.X. Huan, T.N. Anh, N.T. Hang, D.T. Nhung, N.V. Thanh, J. Viet. Env. 9, 255 (2018).

12. S. Stopic, F. Wenz, T.-V. Husovic, B. Friedrich, Metals 11, 463 (2021).
2.4 times). With a further increase in processing time, the value of $D_{e f}$ fluctuates around a certain value.

According to thermal desorption mass spectrometry data, the main volatile products of desorption of $\mathrm{SiO}_{2}$ powders up to $600{ }^{\circ} \mathrm{C}$ are $\mathrm{H}_{2} \mathrm{O}, \mathrm{H}_{2}, \mathrm{O}, \mathrm{OH}, \mathrm{CO}_{2}, \mathrm{CO}_{5}$.

It was shown that the synthesized $\mathrm{SiO}_{2}$ powders have a maximum specific surface area of $64 \mathrm{~m}^{2} / \mathrm{g}$ according to BET and $93 \mathrm{~m}^{2} / \mathrm{g}$ according to Langmuir. The total pore volume is $218 \mathrm{~mm}^{3} / \mathrm{g}$, including $3.7 \mathrm{~mm}^{3} / \mathrm{g}$ of micropores. The total area of micropores is $10.5 \mathrm{~m}^{2} / \mathrm{g}$, the non-microporous surface is $53.4 \mathrm{~m}^{2} / \mathrm{g}$.

So, the proposed synthesis method allows to process the man-made waste of the copper-smelting production of AMMC and obtain from it a dispersed high-purity silicon dioxide powder (99.98 \%) with micron-sized particles and a moderate specific surface area that fully meets the requirements for fillers used in the rubber industry.

\section{ACKNOWLEDGEMENTS}

The authors are grateful to the staff of Chuiko Institute of Surface Chemistry Yu.N. Nychiporuk, N.V. Guzenko, O.A. Dudarko for technical assistance in obtaining data of this research, meaningful discussion, and valuable comments on the results.

13. V.G. Il'ves, M.G. Zuev, S.Yu. Sokovnin J. Nanotechnology, 2015, 417817 (2015).

14. S.P. Bardakhanov, Questions of Atomic Science and Technology. Series: Nuclear Physics Research 5, 165 (2008).

15. A.N. Dyachenko, R.I. Kraydenko, Processing for Profit, Social and Environmental Stewardship Proceedings of the 51Annual Conference of Metallurgists of CIM (COM 2012), 238 (Canada: Niagara, ON: 2012).

16. B.M. Abdurakhmanov, M.Sh. Kurbanov, S.A. Tulaganov, M. Ernazarov, L.S. Andriyko, A.I. Marinin, A.Yu. Shevchenko, Uzbek. Phys. J. 23 No 1, 65 (2021).

17. V.S. Rimkevich, A.A. Pushkin, I.V. Girenko, Basic Mental Research 2, 6055 (2015).

18. V.M. Gun'ko, V.I. Zarko, B.A. Chuikov, V.V. Dudnik, Yu.G. Ptushinskii, E.F. Voronin, E.M. Pakhlov, A.A. Chuiko, Int. J. Mass Spectrom. Ion Proces. 172, 161 (1998).

19. S.J. Gregg, K.S.W. Sing, Adsorption, Surface Area and Porosity (London: Academic Press: 1982).

20. A.W. Adamson, A.P. Gast, Physical Chemistry of Surface, 6th ed. (Wiley, New York: 1997).

21. V.M. Gun'ko, Appl. Surf. Sci. 307, 444 (2014).

22. V.M. Gun'ko, V.V. Turov, P.P. Gorbik, Voda na Mezhfaznoj Granice (Naukova dumka: Kiev: 2009).

\section{Властивості аморфного кремнезему, синтезованого із мідеплавильних шлаків}

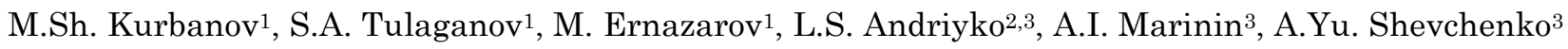

${ }^{1}$ Institute of Ion-Plasma and Laser Technologies named after U.A. Arifov, 33, Durmon Yuli St., 100125 Tashkent, Uzbekistan

${ }^{2}$ Chuiko Institute of Surface Chemistry, 17, General Naumov St., 03164 Kyiv, Ukraine

${ }^{3}$ National University of Food Technology, 68, Volodymyrska St., 01033 Kyiv, Ukraine

3 техногенних відходів мідеплавильного виробництва синтезовано високодисперсні порошки аморфного кремнезему (діоксиду кремнію) чистотою 99,98 \% з використанням фрториду амонію. Аморфний 
стан отриманих зразків кремнезему було підтверджено рентгеноструктурним аналізом. Встановлено, що гранулометричний склад $\mathrm{SiO}_{2}$ у водному середовищі в основному представлений агрегатами (100220 нм) і агломератами агрегатів (1300 та 5500 нм). Показано, що збільшення часу ультразвукової обробки не впливае істотно на бі- або тримодальний характер гранулометричного складу. Ефективний діаметр $D_{e f}$ агломератів частинок кремнезему зменшуеться в 3 рази протягом перших 10 хв ультраз вукової обробки. При подальшому збільшенні часу обробки $D_{e f}$ істотно не змінюеться, а коливаеться навколо деякого конкретного значення. ІЧ спектри зразків кремнезему мають характерні смуги, пов'язані з коливаннями вигину $\mathrm{Si}-\mathrm{O}-\mathrm{Si}$ при 468 см$^{-1}$ (інтенсивні) та O-Si-O при $800 \mathrm{~cm}^{-1}$ (середньої інтенсивності), а також смуги, пов'язані з коливаннями розтягу $\mathrm{Si}-\mathrm{O}-\mathrm{Si}$ в діапазоні 1000-1200 см ${ }^{-1}$, які відповідають за реакційну здатність. Встановлено, що процес термічної десорбції з поверхні зразка $\mathrm{SiO}_{2}$ протікае в кілька етапів, з найбільш інтенсивним виділенням таких основних летких продуктів: $\mathrm{O}(\mathrm{m} / z 16), \mathrm{OH}(\mathrm{m} / z 17), \mathrm{H}_{2} \mathrm{O}(\mathrm{m} / z 18)$ та $\mathrm{CO}(\mathrm{m} / z 28)$. Текстурні характеристики синтезованих порошків визначали методом низькотемпературної адсорбції азоту. Показано, що форма ізотерми адсорбції та петлі гістерезису відповідае текстурній пористості агрегатів непористих наноматеріалів. Ізотерма адсорбції добре лінеаризована, що дозволило розрахувати питому площу поверхні за методами BET $\left(64 \mathrm{~m}^{2} / \Gamma\right)$ і Ленгмюра $\left(93 \mathrm{M}^{2} / \Gamma\right)$, загальний об'єм пор, мікропор і загальну площу мікропор.

Ключові слова: Синтез, Фторид амонію, Промислові відходи, Високодисперсні порошки, Аморфний діоксид кремнію, Гранулометричний склад. 